\title{
HUBUNGAN INFEKSI HUMAN PAPILOMA VIRUS TERHADAP TERJADINYA KETUBAN PECAH DINI DI RSIA SITI HAWA PADANG
}

Fiona Dewanti ${ }^{1}$, Andani Eka Putra ${ }^{2}$, Bobby Indra Utama ${ }^{3}$

\begin{abstract}
Abstrak
Ketuban pecah dini (KPD) adalah pecahnya selaput ketuban sebelum proses persalinan dimulai. KPD merupakan komplikasi yang cukup umum dari kehamilan dan menyebabkan peningkatan morbiditas dan mortalitas perinatal, serta menimbulkan komplikasi pada ibu. Salah satu faktor resiko penyebab KPD adalah adanya infeksi yang berasal dari ibu, dan penyebab infeksi pada wanita diantaranya adalah HPV. HPV merupakan salah satu penyebab terjadinya infeksi menular seksual. Wanita hamil memiliki resiko tinggi terkena infeksi HPV, karena selama kehamilan terjadi perubahan fisiologis dan imunologi dari sistem imun dan bisa saja dapat merubah replikasi dari virus HPVPenelitian ini merupakan studi analitik dengan desain case control, yaitu untuk mengetahui hubungan infeksiHPV terhadap terjadinya Ketuban Pecah Dini di RSIA Siti Hawa Padang. Teknik pengambilan sampel dengan consecutive sampling, yaitu setiap pasien yang memenuhi kriteria inklusi dimasukkan kedalam subjek penelitian sampai jumlah sampel tercukupi, yaitu sebanyak 50 sampel.Hasil penelitian didapatkan tidak terdapat infeksi HPV pada kelompok kasus dan kontrol. Analisa statistik dengan uji Fisher's Exact Test menunjukkan bahwa tidak terdapat hubungan yang bermakna antara tidak terdapat hubungan yang bermakna antara infeksi HPV dengan kejadian KPD (P>0,05).Dari hasil penelitian dapat disimpulkan tidak terdapat hubungan yang bermakna antara infeksi HPV dengan kejadian KPD di RSIA Siti Hawa. Diharapkan untuk penelitian berikutnya melakukan penelitian lanjutan tentang infeksi dari bakteri lain, virus, dan jamur penyebab terjadinya KPD.
\end{abstract}

Kata kunci: Infeksi Human Papilloma Virus, KPD

\begin{abstract}
Early rupture of membranes (KPD) is rupture of the membranes before labor begins. KPD is a fairly common complication of pregnancy and causes increased perinatal morbidity and mortality, and causes complications in the mother. One of the risk factors for the cause of KPD is the presence of infection from the mother, and the cause of infection in women including HPV. HPV is one of the causes of sexually transmitted infections. Pregnant women have a high risk of HPV infection, because during pregnancy there are physiological and immunological changes of the immune system and could possibly change the replication of the HPV virus. This study is an analytic study with a case control design, which is to determine the relationship of HPV infection to the occurrence of premature rupture of membranes. at RSIA Siti Hawa Padang. The sampling technique was by consecutive sampling, that is, every patient who fulfilled the inclusion criteria was included in the research subject until the number of samples was fulfilled, namely 50 samples. The results showed that there were no HPV infections in the case and control groups. Statistical analysis by Fisher's Exact Test showed that there was no significant relationship between no significant relationship between HPV infection and the incidence of KPD (P> 0.05). The results of this study concluded that there was no significant relationship between HPV infection and the incidence of KPD in RSIA Siti Hawa. It is expected that the next research will conduct further research on infections from other bacteria, viruses, and fungi that cause the occurrence of KPD.
\end{abstract} Keywords: HPV infection, PRM

Affiliasi penulis :1. Program Studi Magister S2 Biomedik FK UNAND 2. Bagian Mikrobiologi FK UNAND, 3. Bagian Obstetri dan Ginekologi RSUP Dr. M. Djamil Padang.

Korespondensi :Fiona Dewanti, Andani Eka Putra, Bobby Indra Utama.

email: fionadewanti@gmail.com, Telp: 081363070970

\section{PENDAHULUAN}

Salah satu indikator untuk mengukur derajat kesehatan suatu negara adalah angka kematian ibu (AKI) dan angka kematian bayi (AKB). Menurut World Health Organization (WHO) angka kematian dan kesakitan ibu hamil, melahirkan dan nifas masih merupakan masalah besar yang terjadi di negara berkembang termasuk Indonesia.Dari hasil Survey Demografi dan Kesehatan Indonesia (SDKI) 2015, derajat kesehatan ibu dan anak di Indonesia masih perlu ditingkatkan untuk mengurangi kematian ibu dan anak. SDKI mengungkapkan, Angka Kematian Ibu (AKI), yaitu 305 per 100.000 kelahiran hidup, sedangkan Angka Kematian Bayi (AKB) 22,3 per 1000 kehamilan yang di sebabkan oleh beberapa faktor yang berhubungan dengan masalah keperawatan salah satu penyebabnya yaitu kehamilan yang diakhiri dengan ketuban pecah dini yang menimbulkan komplikasi baik pada ibu maupun bayi ${ }^{1}$.

Ketuban pecah dini (KPD) didefinisikan sebagai pecahnya membran selaput ketuban sebelum terjadinya persalinan. Ketika terjadi sebelum 37 minggu usia kehamilan disebut sebagai premature ruptur of membrane (PROM) dan bila terjadi setelah 37 minggu usia kehamilan disebut istilah KPDpadakehamilan yang aterm. KPD mempersulit 
sekitar $5-10 \%$ kehamilan. Di antara ini sekitar 50\% kasus persalinan dimulai secara spontan dalam 12 jam, 70\% dalam 24 jam, 85\% dalam 48 jam dan 95\% dalam 72 jam. Morbiditas janin yang terkait dengan KPD meliputi infeksi dan kompresi tali pusat. Risiko maternal meliputi chorioamnionitis, endometritis, abrupsi plasenta dan morbiditas demam postpartum. ${ }^{2}$

KPD merupakan komplikasi yang cukup umum dari kehamilan dan bisa menyebabkan peningkatan morbiditas dan mortalitas perinatal serta menimbulkan komplikasi pada ibu. ${ }^{3}$ KPD pada kehamilan kurang bulan mempersulit sekitar $3 \%$ kehamilan dan terjadinya $30-40 \%$ kelahiran prematur ${ }^{4}$.

Banyak faktor risiko untuk KPD yaitu, infeksi intra uterin pada usia gestasi awal, status sosial ekonomi yang rendah, perawatan prenatal yang tidak memadai dan nutrisi yang tidak adekuat selama kehamilan, infeksi menular seksual, perdarahan pervaginam, riwayat ibu yang merokok selama kehamilan. Ibu dan janin beresiko lebih besar terkena infeksi pada kasus KPD ${ }^{5}$

Salah satu faktor risiko penyebab infeksi menular seksual pada wanita adalah Human Papilloma Virus (HPV) dan Chlamydia trachomatis. Pada kebanyakan wanita, infeksi Chlamydia trachomatis seringkali asimtomatis. Pada wanita hamil infeksi Chlamydia trachomatis sekitar 3-10\%. Adanya servisitis mukopurulen bisa menjadi indikator infeksi Chlamydia trachomatis pada wanita hamil. Infeksi Chlamydia trachomatis bisa meningkatkan resiko terjadinya korioamnionitis, kelahiranprematur, ketuban pecah dini dan bayi berat lahir rendah' ${ }^{6}$.

Human Papilloma Virus juga merupakan salah satu penyebab infeksi menular seksual. Wanita hamil memiliki resiko tinggi terkena infeksi HPV,karena selama kehamilan terjadi perubahan fisiologis dan imunologi dari sistem imun dan bisa saja dapat merubah replikasi dari virus HPV7.

RSIA Siti Hawa sebagai rumah sakit rujukan ibu dan anak di kota Padang ditemui angka kejadian KPD pada tahun 2016 adalah 60 kasus dari 2208 total persalinan atau $2,71 \%$ dari total seluruh persalinan ${ }^{8}$.

Berdasarkan uraian diatas peneliti tertarik untuk melakukan penelitian mengenai hubungan infeksi HPV terhadap terjadinya ketuban pecah dini di RSIA Siti Hawa Padang.

\section{METODE}

Penelitian ini merupakan studi analitik dengan desain case control, yaitu untuk mengetahui hubungan infeksiHPV terhadap terjadinya Ketuban Pecah Dini di RSIA Siti Hawa Padang. Teknik pengambilan sampel dengan consecutive sampling, yaitu setiap pasien yang memenuhi kriteria inklusi dimasukkan kedalam subjek penelitian sampai jumlah sampel tercukupi, yaitu sebanyak 50 sampel. Penelitian dilakukan dari bulan November 2017-Februari 2018. Populasi pada penelitian ini adalah semua ibu hamil dengan positif ketuban pecah dini untuk kelompok kasus dan ibu hamil tanpa ketuban pecah dini. Pengumpulan data dilakukan dengan teknik wawancara dengan menggunakan kuesioner dan dilakukan pengambilan apusan endoserviks untuk kedua kelompok kasus dan kontrol, kemudian dilakukan pengolahan data dengan komputerisasi menggunakan SPSS.

\section{HASIL}

Karakteristik sampel berdasarkan umur, paritas, usia kehamilan, lama KPD dan riwayat keputihan.

Tabel 1 Karakteristik Sampel Penelitian Berdasarkan Umur, Paritas, Usia Kehamilan di RSIA Siti Hawa Padang.

\begin{tabular}{lllll}
\hline Karakteristik & \multicolumn{2}{c}{ KPD } & \multicolumn{2}{c}{ NON KPD } \\
& F & $\%$ & F & $\%$ \\
\hline Umur & & & & \\
$<20$ tahun & 1 & 4 & 0 & 0 \\
$\begin{array}{l}\text { 20-35 tahun } \\
>35 \text { tahun }\end{array}$ & 19 & 76 & 23 & 92 \\
\hline Paritas & 5 & 20 & 2 & 8 \\
$\begin{array}{l}\text { Beresiko } \\
\text { Tidak beresiko }\end{array}$ & 2 & 8 & 0 & 0 \\
\hline Usia kehamilan & 23 & 92 & 25 & 100 \\
Aterm & 22 & 88 & 14 & 56 \\
Preterm & 3 & 12 & 11 & 44 \\
\hline Lama KPD & & & & \\
Beresiko & 7 & 28 & 0 & 0 \\
Tidak beresiko & 18 & 72 & 0 & 0 \\
\hline Riwayat keputihan & & & & \\
Ya & 20 & 80 & 20 & 80 \\
Tidak & 5 & 20 & 5 & 20 \\
\hline
\end{tabular}

Berdasarkan tabel 1 dapat dilihat, kelompok umur didapatkan sebanyak $80 \%$ kelompok tidak beresiko mengalami KPD sedangkan kelompok beresiko mengalami KPD sebanyak $20 \%$. Berdasarkan jumlah paritas didapatkan $92 \%$ kelompok tidak beresiko mengalami KPD dan $8 \%$ pada kelompok beresiko. Berdasarkan usia kehamilan $88 \%$ dengan usia kehamilan aterm dan $12 \%$ dengan kehamilan preterm. Berdasarkan lamanya KPD 72\% yang mengalami KPD adalah kelompok tidak beresiko dan $28 \%$ pada kelompok beresiko. Berdasarkan riwayat keputihan $80 \%$ dengan riwayat keputihan selama hamil mengalami KPD dan $20 \%$ pada sampel tidak ada riwayat keputihan sebelumnya.

Tabel 2. Hubungan HPV dengan kejadian Ketuban Pecah Dini di RSIA Siti Hawa Padang

\begin{tabular}{ccccccc}
\hline $\begin{array}{c}\text { Infeksi } \\
\text { HPV }\end{array}$ & \multicolumn{2}{c}{$\begin{array}{c}\text { Kejadian } \\
\text { KPD }\end{array}$} & \multicolumn{2}{c}{$\begin{array}{c}\text { Kejadian } \\
\text { non KPD }\end{array}$} & \multicolumn{2}{c}{ Jumlah } \\
& f & $\%$ & f & $\%$ & N & $\%$ \\
\hline Positif & 0 & 0 & 0 & 0 & 0 & 0 \\
Negatif & 25 & 100 & 25 & 100 & 50 & 100 \\
Jumlah & 25 & 100 & 25 & 100 & 50 & 100 \\
\hline
\end{tabular}

Dari hasil penelitian pada sampel dengan kejadian KPD tidak ditemukannya infeksi HPV begitu juga pada sampel non KPD, sehingga tidak dilakukan uji statistik, maka tidak ada hubungan yang bermakna antara kejadian KPD dengan HPV.

\section{PEMBAHASAN}

\section{Karakteristik Sampel Penelitian}

Berdasarkan hasil penelitian karakteristik sampel berdasarkan umur pada kelompok KPD terbanyak adalah usia tidak beresiko yaitu 20-35 tahun. (80\%) danpadakelompok non KPD juga 
terbanyak pada kelompok tidak beresiko yaitu 23 orang $(92 \%)$.Usia ibu hamil yang ideal adalah usia 20 35 tahun, ibu hamil yang berusia lebih atau kurang dari usia tersebut akan mengalami berbagai macam komplikasi pada kehamilannya, yang juga beresiko terhadap pertumbuhan dan perkembangan janin didalam kandungannya.

Berdasarkan usia kehamilan pada kelompok KPD terbanyak pada usia kehamilan aterm, yaitu 22 orang $(88 \%)$, sedangkan pada kelompok non KPD juga terbanyak pada kelompok aterm yaitu 14 orang (56\%). Berdasarkan lama KPD, pada kelompok KPD yang terbanyak berada pada kelompok tidak beresiko (<24 jam), 18 orang ( $72 \%)$. Kehamilan preterm adalah kehamilan yang beresiko terjadinya KPD, jika KPD terjadi pada kehamilan preterm, akan meningkatkan terjadinya infeksi intra uterin, sehingga meningkatkan morbiditas dan mortalitas janin².

Berdasarkan riwayat keputihan, pada kelompok KPD terbanyak pada kelompok yang mempunyai riwayat keputihan selama kehamilan 20 orang $(80 \%)$, sedangkan pada kelompok non KPD juga terbanyak pada ibu hamil yang mempunyai riwayat keputihan dengan persentase yang sama.

\section{Hubungan Infeksi HPV dengan kejadian KPD}

Berdasarkan tabel 2 dapat diketahui tidak ditemukannya infeksi HPV pada ketuban pecah dini atau pun pada kelompok non KPD di RSIA Siti Hawa Padang, sehingga tidak bisa dilakukan uji statistik. Human papillomavirus (HPV) diketahui lebih banyak terjadi pada aborsi spontan daripada penghentian kehamilan secara elektif. Infeksi plasenta dengan HPV terbukti berhubungan dengan persalinan prematur spontan. Belum banyak penelitian yang membahas hubungan HPV terhadap terjadinya KPD.

Prevalensi infeksi HR-HPV adalah $14,1 \%$ pada 45 kelahiran prematur, 50 kasus ketuban pecah dini, 21 kasus preeklampsi dan 8 pada kasus diabetes mellitus gestasional. Pada penelitian ini tidak menjelaskan infeksi HPV pada kelompok ketuban pecah dini ${ }^{9}$.Human Papilloma Virus merupakan penyebab terjadinya kanker serviks pada wanita. HPV ditemukan 90-95 \% pada karsinoma sel skuamosa serviks. Infeksi HPV pada pasien dengan penyakit menular seksual meningkatkan resiko terjadinya kanke rservik uteri.

\section{SIMPULAN}

Berdasarkan hasil penelitian Hubungan InfeksiHPV terhadap kejadian KPD di RSIA Siti Hawa Padang pada bulan November 2017 - Februari 2018 dapat disimpulkan tidak ditemukan infeksi HPV pada kelompok KPD dan non KPD di RSIA Siti Hawa Padang, tiidak terdapat hubungan yang bermakna antara infeksi HPV dengan kejadian KPD di RSIA Siti Hawa Padang.

\section{UCAPAN TERIMA KASIH}

Penulis mengucapkan terima kasih kepada Kepala dan Staf Laboratorium Mikrobiologi Fakultas Kedokteran Unand, Laboratorium Biomedik FK-Unand yang telah membantu perlakuan dan pemeriksaan sampel.

\section{DAFTAR PUSTAKA}

1. Profil Kesehatan Indonesia Tahun 2015. KEMENKES RI ; 2015.

2. Revathi V, Sowjanya R, Lavanya R. Maternal and Perinatal Outcome in Premature Rupture of Membranes at Term. IOSR Journal of Dental and MedicalSciences; 2014. https://pdfs.semanticscholar.org. diunduh Mei 2017.

3. Kishida $T$, Yamada $H$, Negishi $H$, Sagawa $T$, Makinoda S, Fujimoto $S$. Diagnosis of Aterm Premature Rupture of the Membrane Using a Newly Developed AFP Monoclonal Antibody Test Kit. Japan; 1994. https://www.ejog.org/article/00282243(94)01973-B/pdf. Diunduh Mei 2017

4. Rani, S, Reeti M, Varsha G, Anju H, Jagdish C. Vaginal Flora in Preterm Premature Rupture of Membranes and Their Sensitivity to Commonly Used Antibiotics. Department of Obstetrics \& Gynecology, Department of Microbiology, Government Medical College \& Hospital, Chandigarh, India ; 2014. https://www.nepjol.info/index.php/AJMS/article/.../8 485diunduh Mei 2017.

5. Dars S, Malik S, Samreen I, Ara R. Maternal Morbidity and Perinatal Outcome Inpreterm Premature Rupture of Membranes Before 37 weeks Gestation; 2014. https://www.ncbi.nlm.nih.gov/pubmed/24948992. diunduh April 2017

6. Murtiastutik D. Buku Ajar Infeksi Menular Seksual. Cetakan 1. Surabaya: Airlangga University Press; 2008. HIm 110-116.

7. Kaur H. Does Human Pappiloma Virus Affect Pregnancy Outcomes. An Analysist of Hospital Data 2012-2014. International Journal Of Women's Health and Wellness. Departement Of Epidemiolgy, University Of Nebraska Medical Centre ; 2015. https://clinmedjournals.org/.../international-journalof-wome . diunduh April 2017

8. RSIA Siti Hawa. Medical Record RSIA Siti Hawa Padang. RSIA Siti Hawa Padang; 2016.

9. Cho G, Min KJ, Kim H. High-risk Human Papillomavirus Infection is Associated with Premature Rupture of Membranes. Seoul; 2013. https://www.ncbi.nlm.nih.gov/pubmed/24011340 diunduh Mei 2017 